\title{
Efficiency and Democratic Political Organisation; The Case for the Referendum
}

\author{
BRUNO S. FREY, * Economist, University of Zurich
}

\begin{abstract}
Familiar theories of market failure have diagnosed shortcomings in the economy, but theories of government failure argue that the state is incapable of correcting them. More than that, many criticisms of government implicitly or explicitly see failure as due to fundamental shortcomings of democracy. This paper argues that democratic forms of governments are not necessarily inefficient relative to other types of decisionmaking, for example, authoritarian government, and that if individuals are as rational in their actions and expectations as voters as they are meant to be in the market, then failures attributed to democracy lessen or disappear altogether. The paper demonstrates how more democracy, i.e. the use of the initiative and referendum, may actually improve the efficiency of government by giving the mass of citizens the information and opportunity to frustrate efforts of the classe politique to form a coalition against the voters. Empirical examples are drawn from the experience of Switzerland.
\end{abstract}

\section{The Market Fails, Politics Fails and Democracy Fails ...}

\section{A. Market Failure}

Competitive private markets do not lead to a Pareto-optimal or efficient outcome when there exist external effects or public goods, and when economies of scale lead to monopolistic positions of suppliers. This was the generally accepted message of post-war economic theory. The government (assumed to maximise social welfare) must therefore intervene in order to bring about a more efficient outcome. This conclusion was taken up by policy-makers on the micro-level (e.g. by nationalising enterprises or undertaking structural policies) and on the macro-level (by Keynesian fiscal and monetary policy).

*I am grateful for helpful comments to Iris Bohnet, Reiner Eichenberger and Angel Serna. 
The view dominated the economic scene into the seventies, and it still exists today. Not surprisingly, many politicians cling to this invitation to enlarge the government's activities, but relevant parts of economic theory also maintain this view. For instance, in neoclassical public economics taxes and public prices are determined under the assumption that government maximises social welfare.

\section{B. Government Failure}

The market failure orthodoxy was dramatically affected by the advent of Modern Political Economy (including Public Choice, New Institutionalism, Property Rights and Transaction Costs Analysis) where it is assumed throughout that the government is an endogenous actor within the politico-economic system (for surveys see e.g. Mueller i 989; Eggertsson 1990; Frey 1983). The properties of political decision-making systems are carefully analyzed.

Scholars attached most importance to the 'General Impossibility Theorem' (Arrow I95I, preceded by Condorcet I 795), which stated the fundamental result that under 'reasonable' assumptions, no policy equilibrium among alternatives exists, provided that individual preferences are to count. The voting outcomes reveal cyclical instability and in the case of multidimensional issues outcomes may cover the whole policy space, including inefficient outcomes (McKelvey I 976).

Other political failures were also widely discussed. Due to the public good problem, voters have little incentive to become informed about politics and participate in voting; the median voter outcome resulting from perfect competition between two parties is not in general efficient; not all interests have the same capacity to establish political pressure groups, and bureaucracies and rent-seeking further distort the allocation from efficiency.

On the basis of these and other political failures, it was concluded that government is not able to overcome market failures. Rather, under realistic conditions, political intervention leads even further away from efficiency. A case in point is a government's incentive to create a business cycle (Nordhaus 1989) in order to improve its reelection chances.

\section{Government Failure is More Significant than Market Failure}

The results reached by Modern Political Economy have led many scholars to believe that market failures are less important than political failures. This belief is further strengthened by the rediscovery of Coase's ( 1960$)$ proposition that if property rights are well defined and transac- 
tion costs are low, external effects do not prevent an efficient market solution. In addition, the profits made by monopolistic firms are increasingly seen as an indication that they produce efficiently. According to these results, markets work well and politics works badly (Wintrobe I 987 , pp. 435-6, or Wittman I989, pp. I 395-6). Therefore government intervention should be generally reduced or even completely done away with, and resource allocation reserved for private markets.

\section{Govermment Failure is Democracy Failure}

The analysis of politics within Modern Political Economy invariably deals with democracies. The theoretical finding of cyclical instability is of interest only if individual preferences are to count, or political business cycles are due to discontinuous elections. Political failure is therefore interpreted to consist of fundamental shortcomings of democracy.

This conclusion is brought about by the fact that no alternative political systems are considered. There does not exist any developed theory of authoritarian or dictatorial governments comparable to the economic theory of democracy. (For beginnings, see Tullock, I987, Palda, I992, Wintrobe, I990.) Democratic failures, the most recent example being the missing consistency of politics over time (e.g. Alesina r 988 ) have not yet been analyzed for the case of non-democratic governments; consequently, its possible failures tend to be disregarded.

That democracies are characterised by more significant deviations from efficiency than authoritarian governments is rarely openly said; it is more of a presumption lurking in the background. The feeling is visible in the irritation of many economists about the 'ineffectiveness' or the 'muddle' of decision-making in a democracy. Thus, in a recent conference on transition from planning to the market, an economist spoke of the 'catastrophic effects on the economy of the last three elections in Poland'. This feeling easily turns into a desire for 'orderly' solutions by a government with much authority. Such thinking constitutes in effect a return to the planning myth which holds that society can and should be ordered from above by a strong government. Obviously, such thinking does not understand democracy to be a process based on an agreed set of rules. But democracy is not concerned with end states (see e.g. Barry I988); solutions are not simply adopted but developed. In the course of the democratic process, information is produced, and preferences are shaped in an institutionalised discourse. These are the essential characteristics of democracy, not logical consistency or academic elegance. 


\section{A Reevaluation of 'Failures'}

\section{A. The Need for a Comparative Approach}

The failures identified in the economics literature for the market and political sphere are deviations from exogenously defined criteria of optimality, in particular Pareto efficiency and (time) consistency, i.e. two ideal standards. The axiomatic literature dealing with these issues does not compare the relative efficiency of the various decision-making mechanisms, and therefore falls prey to the charge that it pursues a 'Nirvana approach' (Demsetz 1989). The reason for this disregard of 'comparative institutionalism' which deals with real-life phenomena is that the incentives for (young) scholars in economics strongly favour a rigourous analysis of 'classroom-like exercises' and 'amusing little games' (Kolm I 988, p. I 20; and more generally Leijonhuvfud I 973; Frey and Eichenberger 1992).

Consider the cycling problem when individual preferences are aggregated in a democracy. Many hundreds of papers have been written on this topic (a field of social choice has developed); on the other hand, the massive discontinuities or cycles produced by authoritarian or dictatorial governments have received little or no attention in the economics literature. In fact, there exist major cycles in authoritarian systems. Non-democratic governments depend on the support of various groups. They must take care not to rely on one only because its members would then be able to extract a large share of the rents from the government, or would simply take power themselves. An authoritarian leader is therefore rational to change his main support basis from time to time, say from the military to the urban masses, then to bureaucracy and to the party, and then back to the military (for the case of Hitler see e.g. Breton and Wintrobe I986; another good example is Franco). While such shifts in power bases may not be easy to formalise, they produce strong time inconsistencies in policy measures. They are likely to be much larger than in a democracy, especially as an authoritarian government is not bound by a constitution.

\section{B. Market and Democracy Efficiency Compared}

Decisions via democratic means are no less efficient than via prices provided that the same basic behavioural assumptions about the individuals are made (Wintrobe 1987 , Wittman 1989). That markets are found to work better than democracy is, to a large extent, the result of assuming that individuals as political actors are more stupid than in the 
market. If a higher degree of citizens' rationality is taken to be realistic, the failures attributed to democracy are lessened or disappear altogether.

Cycling. A small alteration in assumption about voters' behaviour, namely that they favour a given issue with a certain probability (instead of fully supporting or rejecting it) leads to policy outcomes within the efficient set (Wittmann I989, pp. I 4 I $3^{-}$- 5). Individuals who are reasonably sensible are aware that unconstrained voting may lead to inconsistencies, and therefore take action to overcome such failures. The 'structure induced equilibria' favouring efficient outcomes are one instance of what might be called superrationality. Individuals are cognitively able to see that the way they act does not lead to rational results and they are rational enough to improve on it. Another case is weakness of will or akrasia, where people act irrationally in the sense that they behave in a way not desired by themselves (e.g. they smoke, drink or eat too much), but they are rational enough to be aware that they behave in a non-desired way and take action against this weakness by self-commitment (Sen I979; Schelling i 980; Hirschman 1982; Elster I 986; Maital 1986; Frey and Eichenberger i 989). Possibilities are stopping rules (so that defeated proposals may not reappear), agenda setting, voting on one dimensional issue at a time (so that Black's (1958) single-peakedness conditions are more likely to hold), and logrolling (see Mueller 1989 , pp. 89-95). Indeed, democratic voting is in reality characterised by much stability (Tullock I98I; Shepsle and Weingast 198I), and it has also been shown by experiments that such political institutions tend to lead to efficient outcomes (Fiorina and Plott 1978).

Information. Citizens are better informed than has been previously assumed if one takes into account the purpose at hand. It is rational to be less informed about public policy than about a private good one intends to consume, but party brand names and candidate reputations help to make consistent and reasoned decisions. Individuals do not have to know the production process; they can rely on the fact that the politicians' need for reelection induces them to propose and undertake policies that do not deviate systematically from efficiency. To fool the voters constantly is impossible, provided that there is a competitive struggle for citizens' votes, which is indeed a well-taken definition of democracy (Schumpeter I942; Downs 1957).

Transaction costs. In analogy to Coase's proposition, if these costs are not too high, contracts between politicians are able to overcome failures in democratic markets. Transaction costs tend to be low as politicians constantly interact with each other, and the tradition of compromise is well developed. 
Pressure groups. When the amount of pressure exerted by interest groups is a function of their utility gain or loss, then the net political pressure leads towards efficiency (Becker 1983, i 985 ).

All these arguments are not to say that there are no democracy failures. Indeed, empirical research has been able to identify many cases in which democracy, compared to a textbook view of efficiency, produced inefficient outcomes. One example is protectionism, where well organised groups are able to distort resource allocation at the expense of non-organised consumers and tax payers (see e.g. Frey 1984; Magee, Brock and Young 1989). However, the arguments point to forces which work in the direction of efficiency for democracy; the underlying assumptions perform the same role as under competitive market conditions. The discussion thus reveals a strong similarity between market and democracy. In both decision-making systems, individual preferences are the measuring rod for efficiency, and both are process-oriented. The 'invisible hand' not only guides competitive market processes but also competitive democratic processes. It follows that in order to evaluate efficiency, the difference between market and democratic decision-making is of lesser importance than another dimension, namely the extent of competitiveness.

\section{Competitiveness of Political Organisations}

Competitive economic or political markets require free entry (and exit), the absence of regulations which prevent the success of suppliers with the best product (goods and politics), and the demanders being able to choose freely. These requirements seem trivial, but in practice they are often not fulfilled. Even institutions which have been created with the purpose of invigourating competition often strongly violate them. A case in point is the European Community, which, on the one hand, strengthens competition by reducing or eliminating national protectionism in goods, services, capital and labour, but on the other hand introduces a large number of homogenising regulations and laws which suppress competition as they make it impossible for suppliers to exploit comparative cost advantages.

\section{A. Federalism}

Among the institutions which serve to establish competition among political organisations, federalism is of particular interest. It is a rather neglected institution, though the United States, Canada, Australia, Germany, Austria and Switzerland have established this type of competition 
between national subunits. However, even there the provinces and communes are severely restricted in offering a fiscal policy mix which would attract citizens and firms to locate within their borders. In several of the 'federalist' countries mentioned, the local governments are, for example, not free to set their own taxes, and the central government imposes strict regulations and interferes directly in a large number of areas.

Many highly developed and democratic countries do not know federal competition at all, prominent examples being France, the Netherlands and Sweden. While the European Community is still a union of independent states, its constitution is strongly biased towards centralisation, a fact that is already visible in the strong role of the Commission and the European administration (Eurocrats) in Brussels. The future development does not point towards a strong role of competition between the various political subunits in the EC. It is more likely that the politicians in power are able to push through a barrage of homogenising rules and regulations which insulate them from the demands of the citizens and allow them to collect all kinds of rents. Once the Ecu is established, for instance, national politicians will be freer than today to pursue an inflationary policy on the EC level, because they have less fear that they lose reputation and credibility, and that their currency is devalued.

The potential offered by federalism (see Tiebout 1956 and Oates 1977) to establish a vigorous competition between governmental units has so far not been rationally designed by any country. The principle of 'fiscal equivalence' (Oates I977), stating that the size of the political decision-making unit should be determined so that the spatial effects of benefits and costs of a publicly supplied good match, seems to exist in the United States and Switzerland, yet even there to a very limited extent only. Each public function, say, education, police, fire protection, or, if not privatised, refuse collection, could be allocated to a particular political unit whose geographic extension varies according to the particular supply conditions.

Multiple functional and overlapping jurisdictions exist in the Swiss Canton of Thurgau which, with a population of only 200,000 has several hundreds of such political communes, each with corresponding taxes. Not surprisingly, the cantonal government, parliament and administration are not fond of this democratic 'muddle' and make efforts to suppress this lower-level competition, wrongly arguing that it is 'inefficient'. But this 'inefficiency' refers at best to administrative cost, but in particular does not take into account the benefits by supplying more closely to the citizens' preferences, and neglects the better adjustment to changing circumstances of the future. The citizens are, however, not completely free to choose which service they want to enjoy (e.g. they cannot send 
their children to have their basic education wherever they choose), but a limited amount of competition exists as communes as a whole may switch to other suppliers, and as citizens and firms may decide where they locate themselves, and they may exert their voting rights in the various communes, usually taking the form of citizens' assembly (see Casella and Frey r992).

\section{B. Decision-Making}

Modern Political Economy tends to assume that in a democracy there is a competition for votes. Attention has been paid to the fact that in representative democracies elections take place discontinuously and that this enables politicians partly to pursue their own goals (see the literature on political business cycles as reviewed e.g. in Schneider and Frey I 988 and Nordhaus 1989). Taking the citizens to be the principals, and the politicians to be the agents, it has also been studied to which extent shirking occurs, in particular how far legislators pursue their own ideological goals instead of following the voters' preferences (e.g. Kau and Rubin 1979, Kalt and Zupan 1984).

What has been little considered in the literature is the fact that in democracies the politicians may establish a coalition against the voters and taxpayers. An extreme version is Brennan and Buchanan's (1980) exploitative government, which maximises its own revenue. The 'ins' are, under realistic conditions, able to erect entry barriers for contenders and put new entrants at a disadvantage at elections and in parliament. This can, for instance, be done by favouring the established parties when campaign contributions are handed out (see e.g. Pommerehne and Lafay I 983 ), by refusing newly elected parties the status of parliamentary fractions (with all the money and privileges going with it, see e.g. von Arnim 1988), or by instituting parliamentary rules to their disadvantage.

However, newly entering legislators and parties soon belong to the political establishment: even when their basic ideologies widely differ from the longer sitting members, they quickly realise that the benefits and costs have become quite different from the non-politicians. As predicted by the economic model of human behaviour (Becker 1976; Kirchgässner I99I), politicians respond to the opportunities and incentives given by their position, and after a short time they no longer behave differently from all the other 'ins'. They adjust so fully that they find it difficult to comprehend why the 'outs' feel differently; they observe with astonishment that the basis they come from has moved away (as they see it), while in reality they have changed their own behaviour. The coalition of politicians against the voters thus is not restricted to the politi- 
cians in power, but covers the whole classe politique and includes public administrators serving the politicians.

One of the important means for the coalition of politicians to reap benefits is its agenda setting power. As has been shown in Public Choice (e.g. Denzau 1985), the group which can determine in which order the propositions are voted on has an important advantage. What matters more here is what issues are discussed by the politicians and which ones evaded. In most parliaments, for instance, questions of politicians' salaries, compensation for failing reelection, all sorts of pensions and other privileges are not openly discussed or formally voted upon, or only in a disguised way, and then by acclamation.

The politicians united in a coalition also have an interest in blocking constitutional changes which would hurt them by giving greater voice to the 'outs', the citizens. Most importantly, no government and parliament is willing to change voting rules which give them a reelection advantage. One example is the majority (or plurality) voting system in the United Kingdom which drastically benefits the politicians and large parties sitting in parliament. If the election system was changed to proportional voting, outsiders - especially the Liberals - would get a much higher share of parliamentary seats. Another example refers to Switzerland (see Blankart 1992), where in the nineteenth century the plurality principle gave the Radical-Democratic Party an absolute majority for over seven decades in the two houses of parliament, enabling them to form a one-party executive. Efforts by outsiders to change the constitution were regularly blocked by the government and parliament.

The classe politique also prevents constitutional changes restricting their discretionary power. In Switzerland, between 1848 and 1946, parliament had the right to declare federal laws as 'urgent' (dringliche Bundesbeschliusse), so that they did not have to be submitted to the optional popular referendum. Not surprisingly, the politicians used this right extensively; especially in the 193 os many laws were labelled urgent in order not to have to share power with the 'outs'. A final example showing the empirical relevance of politicians forming a coalition against voters refers again to Switzerland. In $1985 / 86$, the government decided that the country should become a member of the United Nations. All the politicians with very few exceptions strongly supported this move, i.e. the parliament, all major parties, all major interest groups, bureaucrats, diplomats and the journalists all agreed on the desirability of UN membership. This support is not surprising as these politicians and public officials were likely to benefit directly or at least indirectly. 


\section{Efficiency by Popular Referenda}

Four formal kinds of direct participation of the citizens in political decision-making may be distinguished: ( 1 ) a popular meeting, such as New England town meetings or Landsgemeinden in some Swiss cantons; (2) obligatory popular referendums; (3) optional popular referendums requiring a certain number of signatures; (4) popular initiatives which force a referendum on a substantive issue. These institutions of political decision-making enable the voters to effectively make their preferences known to the politicians and, perhaps even more importantly, to break up the politicians' coalition against the voters. They must be distinguished sharply from non-binding referenda and plebiscites, which both serve the politicians to consolidate their power vis-à-vis the citizens (cf. Butler and Ranney 1978.

The initiative is a particularly important institution because it takes away the agenda-setting monopoly from the politicians and makes it possible for the 'outs' to propose issues for democratic decisions including those that the politicians would much prefer not to raise, such as matters concerning their income, privileges and discretionary power.

That direct democracy is indeed effective for - at least partly - breaking the politicians' coalition against the voters can be shown in the case of Switzerland. It should be noted that in representative democracies it is much more difficult to detect when such a coalition exists, because the citizens have much higher costs to express their deviating preferences. They have to resort to either informal protest, which is difficult to organise and to make politically relevant, or they have to wait until election time, where they will all the same find it difficult to express specific demands on substantive issues. In Switzerland, on the other hand, citizens may regularly participate in political decisions via referenda at federal, cantonal and communal level. Between 1848 and 1990 , there were 146 obligatory referenda on constitutional issues, I 02 optional referenda on laws, 182 initiatives (which were instituted in 1891 ) alone at the federal level, and many more at the other levels (for an account of the Swiss referendum system see e.g. Hertig 1984; on Swiss institutions, see Aubert 1974; de Rougemont I965). Many decisions of the politicians, which were clearly to their benefit, were turned into referenda by the voters: (1) Proportional voting for parliament (the Nationalrat) which the politicians rejected, was adopted by the citizens in 1918. In the subsequent elections, the Radical-Democratic lost 40 per cent of their seats. (2) A popular initiative undertaken in 1946 succeeded in making 'urgent' federal laws subject to an obligatory referendum within one year. (3) A referendum on Switzerland joining the United Nations resulted in a rejection by 76 per cent of the votes. In all these cases, the politicians in the 
government and parliament had formally decided the opposite. The voters were, however, not prepared to decide in favour of the politicians' cartel, but rather reduced its power.

Econometric cross-section studies for Switzerland (Pommerehne I 978,1990 ) reveal that the political decisions with respect to publicly supplied goods correspond the better to the voters' preferences, the more extensively developed the institutions of direct political participation are. As it is the individual taxpayers and not the politicians who have to bear the cost of government activities, it is not surprising that in political communities with particularly well-developed institutions of direct democracy, public expenditures are ceteris paribus lower.

Referenda not only serve to break up the politicians' coalition by destroying their monopoly of agenda setting, but they also focus the political discussion on substantive issues. This is not the case if, as in California, there are a large number of propositions put forth on a particular day. In Switzerland, on the federal level, there are usually two to three issues at a time. As a result, the citizens are offered information free of charge.

Public Choice has overlooked another consequence of referenda because this theory limits itself to decision aspects. Before a vote is taken, the public discussion induced shapes the citizens' preferences in the sense that the individuals are confronted with political issues they have not considered before, and which they learn to evaluate according to their constant basic preferences (see Stigler and Becker 1977). While this discourse does not meet the strict conditions of an 'ideal' and 'nonimposed' discussion among free people (Habermas ı 983 ; Höffe ı 985), referenda constitute the best practically feasible and institutionalised form of interaction between citizens (Frey and Kirchgässner 1992).

The idea of referenda is often rejected especially by intellectuals, because the citizens are said to be of insufficient intelligence and education to grasp and reasonably decide upon political issues; this task must be left to an elite. This is analogous to the intellectuals' animosity to the market as discussed by Stigler (1984). For Switzerland, a political scientist voices the widespread opinion among social scientists that a referendum democracy 'reduces governmental efficiency of performance and the capacity to innovate' (Hertig 1984, pp. 254-255; my translation). Such a charge is unacceptable if one takes individuals' preferences as the normative base for evaluation, because it assumes that there exists an independent 'social will' according to which a government's 'efficiency' and 'innovation' is good as such. Following the individualistic view, however, this type of technocratic activity can well be incompatible with the citizens' preferences, in which case 'efficiency' and 'innovation' are harmful rather than good. There is, of course, room for an elite 
also in a direct democracy, namely to work out the details and assess the consequences of the various political issues at hand.

\section{Conclusions}

There is little point in confronting market efficiency with political inefficiency; what matters is the extent of competition in both the economic and the political markets. At the constitutional level, it is important to ensure that both areas are open to the entry and activities of factors of production as well as ideas. In the political area, the institutions of federalism especially in the form of multiple, functional and overlapping governmental units - and of direct democracy, serve well to enable citizens to express their preferences and to break the coalition of politicians against voters. In particular, the popular initiative introduces issues which in a representative democracy tend to be suppressed by the agenda setting monopoly of the politicians.

Referenda are rarely used in modern democracies; Switzerland is by far leading in this respect. Of the roughly 500 referenda made at national level between 1793 and 1978, 300 or 6o per cent were held in Switzerland. The second most intensive use occurs in Australia with just 40 referenda or 8 per cent (Butler and Ranney 1978). Moreover on most rankings of per capita national income or of social indicators (see e.g. Review of Economics and Statistics $199^{1}$ or 1992), Switzerland is placed on top. In Eastern Europe, where the constitutions have to be developed anew and where the politico-economic structures are not yet ossified (see Olson 1982), federalism and referenda should be considered as a means of invigourating political competition. The emerging European Community constitution relies on 'democratisation' via strengthening the parliament and the Supreme Court. According to our analysis, these political institutions are not well suited for enabling the citizens to express their preferences, and they may even contribute further to the cartel of the politicians against the voters.

\section{REFERENCES}

Alesina, Alberto A. ( 1988 ) Macroeconomics and Politics. In: Stanley Fischer (ed.), NBER Macroeconomics Annual, Cambridge, Mass: MIT Press: I I-55.

Alesina, Alberto A. $(1989)$ Politics and business cycles in industrial democracies. Economic Policy $4(8), 55-98$.

Arnim, von, Hans H. ( 1988$)$ Macht macht erfinderisch. Der Diätenfall: ein politisches Lehrstïck. Zürich: Edition Interform.

Arrow, Kenneth J. (1951) Social Choice and Individual Values. New York: John Wiley \& Sons.

Aubert, Jean-François (1974) Petile Histoire Constitutionelle de la Suisse. Bern: Francke.

Barry, Norman P. (1988) The Invisible Hand in Economics and Politics. Hobart Paper I 1, London: Institute of Economic Affairs. 
Becker, Gary S. ( 1976) The Economic Approach to Human Behavior, Chicago: Chicago University Press.

Becker, Gary S. ( 1983 ) A Theory of Competition among Pressure Groups for Political Influence. Quarterly Joumal of Economics 98 (Aug.): $371-400$.

Becker, Gary S. (1985) Public Policies, Pressure Groups, and Dead Weight Costs. Journal of Public Economics 28: $329-47$.

Black, Duncan (1958) The Theory of Committees and Elections. Cambridge: Cambridge University Press.

Blankart, Charles B. (1992) A Public Choice View of Swiss Liberty. Paper prepared for the Liberty Fund Colloquium on 'The Swiss Experience with Federal Liberty', Brunnen, Switzerland, March 27-9, $199^{2}$.

Brennan, Geoffrey and Buchanan, James M. ( 1980 ) The Power to Tax. Analytical Foundations of a Fiscal Constitution. Cambridge: Cambridge University Press.

Breton, Albert and Ronald Wintrobe (1986) The Bureaucracy of Murder Revisited, Joumal of Political Economy 94 (5): 905-26.

Butler, David and Austin Ranney (1978) Referendums. A Comparative Sludy of Practice and Theory. Washington: American Enterprise Institute.

Casella, Alessandra and Bruno S. Frey (1992) Federalism and the Theory of Clubs: Towards an Economic Theory of Overlapping Political Jurisdictions. European Economic Review 36 (April): $639-46$.

Coase, Ronald H. (1960) The Problem of Social Cost. Journal of Law and Economics 3 (Oct.), 1-45.

Condorcet, Marquis de (1795) Esquisse d'un tableau historique du progrès de l'esprit humain. Paris: Diannyère.

Demsetz, Harold (1989) Efficiency, Competition and Policy. Oxford: Blackwell.

Denzau, Arthur T. (1985) Constitutional Change and Agenda Control. Public Choice 47: 183-217.

Downs, Anthony (r 957) An Economic Theory of Democracy. New York: Harper and Row.

Eggertsson, Thrainn ( 1990 ) Economic Behaviour and Institutions: Principles of Neoinstitutional Economics. Cambridge: Cambridge University Press.

Elster, Jon (ed.) (1986) The Multiple Self. Cambridge: Cambridge University Press.

Fiorina, Morris P. and Charles R. Plott (1978) Committee Decisions under Majority Rule: An Experimental Study. American Political Science Review 72 (June): 575-98.

Frey, Bruno S. ( 1983$)$ Democratic Economic Policy. Oxford: Blackwell.

Frey, Bruno S. ( 1984$)$ Intemational Political Economics. Oxford: Blackwell.

Frey, Bruno S. and Gebhard Kirchgässner (1992) Diskursethik, Politische Ökonomie und Volksabstimmungen. Discussion paper, Institute for Empirical Economic Research, University of Zurich, February 1992.

Frey, Bruno S. and Reiner Eichenberger (1989) Should Social Scientists Care about Choice Anomalies? Rationality and Society I (July): 101-22.

Frey, Bruno S. and Reiner Eichenberger (1992) Economics and Economists: A European Perspective. American Economic Review 82 (May): 216-20.

Habermas, Jürgen ( 1983$)$ Diskursethik - Notizen zu einem Begründungsprozess. In: Jürgen Habermas (ed.), Moralbewusstsein und kommunikatives Handeln. Frankfurt: Suhrkamp: 53-125.

Hertig, Hans Peter( 1984$)$ Volksabstimmungen. In: Klöti, Ulrich (ed.). Handbuch des Politischen Systems der Schweiz, Vol. 2, 247-77. Bern: Haupt.

Hirschman, Albert O. (1982) Shifting Involvements. Private Interests and Public Action. Oxford: Martin Robertson.

Hirschman, Albert O. (1982) Shifting Involvements. Private Interests and Public Action. Oxford: Martin Robertson.

Hirschman, Albert O. (1982a) Rival Interpretations of Market Society: Civilizing, Destructive, or Feeble? Joumal of Economic Literature 20 (Dec.), $1463-84$.

HöfTe, O. ( 1985$)$ Strategien der Humanität: Zur Ethik öffentlicher Entscheidungen. Frankfurt: Suhrkamp.

Kalt, J. H. and M. A. Zupan ( 1984 ) Capture and Ideology in the Economic Theory of Politics. American Economic Review 74 (June): 279-300.

Kau, J. B. and P. N. Rubin (I 979) Self-Interest, Ideology and Logrolling in Congressional Voting. Journal of Law and Economics 22 (Oct.): $365-84$.

Kirchgässner, Gebhard (rg9r) Homo Oeconomicus. Das Ökonomische Modell individuellen Verhaltens und seine Anwendung in den Wirtschafts- und Sozialwissenschaften. Tübingen: Mohr (Siebeck).

Kolm, Serge-Christoph (1988) Economics in Europe and in the U.S., European Economic Review, 32, 207-12. 
Leijonhufvud, Axel (1973) Live Among the Econ. Western Economic Journal I I (Sept.), 327-37.

Magee, Stephen P., William A. Brock and Leslie Young (1989) Black Hole Tariffs and Endogenous Policy Theory. Political Economy in General Equilibrium. Cambridge: Cambridge University Press.

Maital, Shlomo ( 1986 ) Prometheus Rebound: On Welfare-Improving Constraints. Eastern Economic Journal i 2 (July-Sept.), 337-43.

McKelvey, Richard D. (1976) Intransitivities in Multidimensional Voting Models and Some Implications for Agenda Control. Joumal of Economic Theory i 2 (June): 472-82.

Mueller, Dennis C. (1989) Public Choice II. Cambridge: Cambridge University Press, 2nd ed.

Nordhaus, William D. (1989) Alternative approaches to the political business cycle. Brookings papers on economic activity $2: 1-68$.

Oates, Wallace E. (1977) The Political Economy of Fiscal Federalism. Lexington, Mass.: D.C. Heath.

Olson, Mancur ( 1982 ) The Rise and Decline of Nations: Economic Growth, Stagflation, and Social Rigidities. New Haven: Yale University Press.

Palda, Filip (1992) Can Repressive Regimes be Moderated Through Foreign Aid? Public Choice.

Pommerehne, Werner W. (1978) Institutional approaches to public expenditure: Empirical evidence from Swiss municipalities. Joumal of Public Economics 9 (April): 255-80.

Pommerehne, Werner W. (1990) The Empirical Relevance of Comparative Institutional Analysis. European Economic Review 34 (May): $45^{8-69}$.

Pommerehne, Werner W. and Jean-Dominique Lafay $\left(\mathrm{s}^{8} 8_{3}\right)$ Ökonometrische Untersuchungen von Wahlkampfausgaben: Ein Überblick. Jahrbuch für Sozialwissenschaft 43: 20-58.

Rougement, Denis de (1965) La Suisse: On L'Histoire d'un Peuple Heureux. Paris: Hachette.

Schelling, Thomas C. (1980) The Intimate Contest for Self-Command. Public Interest 6o (Summer): 94-1 18.

Schneider, Friedrich and Frey, Bruno S. (1988) Politico-Economic Models of Macroeconomic Policy: A Review of the Empirical Evidence. In: Willett, Thomas D. (ed.). The Political Economy of Money, Inflation and Unemployment. Durham and London: Duke University Press, 240-75.

Schumpeter, Joseph A. ( 1942 ) Capitalism, Socialism and Democracy. Allen \& Unwin, London.

Sen, Amartya K. (1979 Rational Fools: A Critique of the Behavioural Foundations of Economic Theory. In Hahn, Frank and Hollis, Martin (eds.), Philosophy and Economic Theory, Oxford: Oxford University Press, 87-109. Reprinted in: Sen, Amartya K., Choice, Welfare and Measurement, Oxford: Blackwell, $1982,84-107$.

Shepsle, Kenneth A. and Weingast, Barry R. (1981) Political Preferences for the Pork Barrel: A Generalization, American Joumal of Political Science 25, I (February): 96-111.

Stigler, George J. (1972) Economic Competition and Political Competition. Public Choice 13 (Fall): $91-106$.

Stigler, George J. (1984) The Intellectual and the Marketplace. Cambridge, Mass.: Harvard University Press.

Stigler, George J. and Gary S. Becker ( 1977 ) De Gustibus Non Est Disputandum. American Economic Review 67 (March): 76-9o.

Tiebout, Charles M. (1956) A Pure Theory of Local Expenditure. Journal of Political Economy 64 (October): 416-24.

Tullock, Gordon (I98I) Why so much stability? Public Choice 37: 189-205.

Tullock, Gordon ( 1987 ) Autocracy. Dordrecht: Kluwer.

Vaubel, Roland and Thomas D. Willett (eds) ( $199 \mathrm{I}$ ), The Political Economy of International Organisations: A Public Choice Approach. Denver: Westview Press.

Wintrobe, Ronald ( $19^{87}$ ) The Market for Corporate Control and the Market for Political Control. Joumal of Law, Economics, and Organization 3 (Fall): 435-48.

Wintrobe, Ronald (r 990) The Tinpot and the Totalitarian: An Economic Theory of Dictatorship. American Political Science Review 84 (3): 849-72.

Wittman, Donald ( 1989 ) Why Democracies Produce Efficient Results. Joumal of Political Economy 97 (Dec): 1395-1424. 